\section{Decay in advanced Alpine Fir Regeneration in the Prince George District of British Columbia}

\author{
by R. B. Smith and H. M. Craig
}

\begin{abstract}
The incidence, extent, and causal fungi of decay was investigated in alpine fir advanced growth up to 7 inches $d b h$ and 7 to 246 years of age from logged and unlogged white spruce-alpine fir stands in the Prince George District. Decay was most serious in the older and larger trees, in trees with suspect indicators, and in those with poor crowns and malformed boles. Management recommendations for recently cut-over areas include removal of residual trees over 6 inches $d b h$, and of trees with certain suspect indicators in the 3-6 inch dbh classes. Variations in recommended stand improvement procedures are discussed.
\end{abstract}

\section{Extrait}

Les auteurs étudient la présence et l'étendue de la pourriture causée par les champignons sur les Sapins concolores (Abies lasiocarpa) venus naturellement, dont le diamètre (d.h.p.) maximal mesure 7 pouces et dont l'âge varie de 7 à 246 ans, clans certains peuplements vierges ou exploités, mêlés d'épinettes blanches (Picea glauca) et de sapins concolores et situés dans la région de Prince George, Colombie Britannique. Les arbres les plus vieux et les plus grands étaient les plus atteints, de même que les individus présentant certains symptômes et ceux qui avaient une cime mal développée ou un fût difforme. Les mesures d'aménagement suivantes sont recommandées, pour ce qui concerne les aires récemment exploitées: enlever les arbres estants dont le diamètre (d.h.p.) dépasse 6 pou., de même que les sujets malades à diamètre de $3 \dot{a} 6$ pou. Ce traitement peut varier jusqu'à un certain point.

\author{
Research Scientist \\ and Technicion. \\ (Forest Research), \\ respectively, \\ Department of \\ Forestry and Rural \\ Development, \\ Forest Research \\ Loboratory. \\ Victoria, B.C. \\ Oxf. 844-2: \\ $174-7(711)$
}

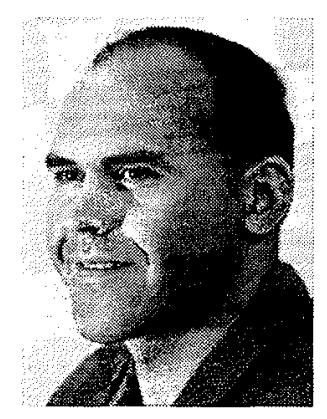

R. B. Smith



H. M. Craig

\section{Introduction}

In logged spruce-alpine fir stands in the Prince George District, alpine fir (Abies lasiocarpa (Hook.) Nutt.) generally outnumber spruce (mainly Picea glauca (Moench) Voss). The potential productivity of these residual stands has been the subject of considerable controversy (McKinnon, 1940; Silburn, 1960; Addison, 1966), primarily because alpine fir is extremely susceptible to heart rot (Dickson, 1927; Bier et al., 1948; Browne, 1952). Cull factors published by the British Columbia Forest Service (1946 allow for $24 \%$ decay in alpine fir over 11 inches dbh.

Previous decay investigations were concerned with merchantable size classes. This study was undertaken to obtain data for advanced alpine fir regeneration up to 7 inches $\mathrm{dbh}$ and to establish criteria for individual trees and stands that would facilitate estimating their potential productivity.

\section{Methods}

Fifteen 0.1 or 0.2 -acre plots were established in logged and unlogged stands. The $\mathrm{dbh}$ of all living trees within the plots were tallied and the heights of several dominant and codominant spruce and alpine fir measured." Minor vegetation and soil profiles were described.

Ten trees from each 1 -inch $\mathrm{dbh}$ class and from trees less than 4.5 feet in height, were selected for decay analysis in each plot and were assigned the following decadence ratings:

Class I - with no suspect indicators (Foster et al., 1953)

\footnotetext{
In cut-over areas heights were token in adjacent uncut stonds. "The term "suspect indicators" is used to denote visible characters of a tree that would lead one to suspect that the tree contained internal decay.
} 
Class II - with at least one of the following
suspect indicators: conks, broken tops, dead branch stubs, dead tops, scars, crooks with without green or dead secondary leaders, ${ }^{4}$ dead branches, swellings, forks, and burls.

A record was made of the location and size of each indicator. The trees were also classified as poor or moderate or good, based on crown density, color, uniformity, and length, dead branches, multiple leaders, and bole deformities.

After this evaluation, the trees were felled and dissected systematically along the bole and at all suspect points. Ages were counted, often with the aid of a magnifying lens or dissecting microscope, at each regular dissection point, and diameters measured for gross volume computations. Decay measurements included; extent of advanced decay, stains obviously associated with advanced decay, and stains not associated with decay if decay fungi were cultured from them. Stains not found infected were disregarded. Probable avenues of entrance of the decay fungi were recorded.

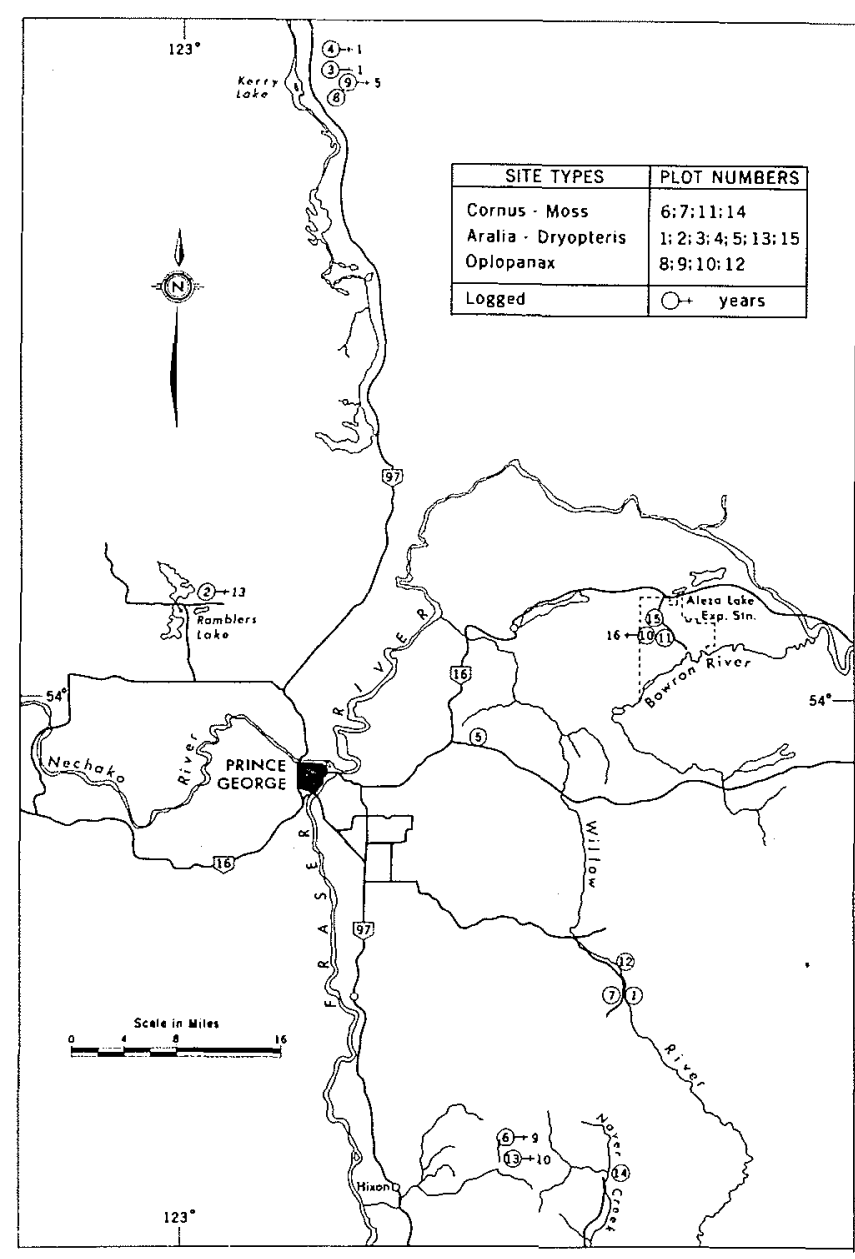

Figure 1.

Location, site type, and number of years since logging of atpine fir advanced regeneration plots.

"Secondary leaders were formerly main leaders or multiple leaders which were later outgrown.

\section{Area of Study and Description of Types}

Plots were located in the Sub-boreal Spruce Zone (Krajina, 1965) to the northwest, north, east, and south of Prince George (Fig. 1), in three of the forest types described by Arlidge (Illingworth and Arlidge, 1960). Brief descriptions of the plots follow:

Oplopanax - four plots (two logged); three plots fine-textured Gleyed Orthic Gray Wooded soils of lacustrine, alluvial, or outwash origin, and one plot coarse-textured alluvial flood plain Regosol; some incipient Podzol Ae; site index at 100 years (SI 100) for spruce $=100$; SI 100 alpine fir $=80$; relatively low density of understory 1-6 inches dbh; low proportion of spruce in the understory (Table 1).

Table 1

AVERAGE NUMBER OF UNDERSTORY SPRUCE AND ALPINE FIR PER ACRE FOR THREE SITE TYPES

\begin{tabular}{lcccc}
\hline & \multicolumn{4}{c}{$\begin{array}{c}\text { No. of trees per } \\
\text { acre }\end{array}$} \\
Site type & $\begin{array}{l}\text { No. of } \\
\text { plots }\end{array}$ & \begin{tabular}{c}
$\left(0.6-6.5^{\prime \prime}\right.$ dbh $)$ \\
\cline { 3 - 5 }
\end{tabular} & $\begin{array}{c}\text { Ratio } \\
\text { alpine fir } \\
\text { to spruce }\end{array}$ \\
\hline $\begin{array}{l}\text { Oplopanax } \\
\text { Aralia -- Dry- }\end{array}$ & 4 & 19 & 514 & 27.1 \\
$\begin{array}{l}\text { opteris } \\
\text { Cornus - Moss }\end{array}$ & 7 & 38 & 847 & 22.3 \\
\hline
\end{tabular}

Aralia-Dryopteris - seven plots (two logged): six plots Brunisolic, Orthic, and Bisequa Gray Wooded soils; one plot Orthic Podzol on coarse material; parent materials varied from lacustrine silt to glacial till sandy loam; SI 100 spruce $=$ 90: SI 100 alpine fir $=80$; understory 1-6 inches $\mathrm{dbh}$ much denser and proportion of spruce higher than in Oplopanax type (Table 1).

Cornus-Moss - four plots (one logged); two plots on coarse sandy alluvium with Ortstein Podzol profiles; one plot coarse and one plot fine-textured Brunisolic Gray Wooded soil, the latter being wet but with low $\mathrm{pH}$ values characteristic of Cornus-Moss soils; SI 100 spruce $=$ 70; SI 100 alpine fir $=70$; understory $1-6$ inches dbh most dense of all the site types, and with highest proportion of spruce (Table 1).

\section{Basis of Results}

From 410 trees less than 0.6 inches dbh (including trees under 4.5 feet in height), and 874 trees $0.6-6.5$ inches $\mathrm{dbh}^{5}$, approximately 2,635 suspect points were analysed for decay, and 387 samples were cultured.

"Eight trees in the 7-inch dbh class were taken in two plots because of a shortage of 6-inch trees. In all analyses, these were included with the 6 -inch class. 


\section{Decay in Relation to Diameter}

Both the volume and incidence of decay increased with increasing tree diameter (Table 2). Only $1 \%$ of the trees less than 0.6 inches dbh were infected and no decay deductions were necessary. Deductions were required for trees larger than 1 -inch $\mathrm{dbh}$, but neither the volume $(1.4 \%)$ nor incidence $6.3 \%$ of decay was serious in trees less than 3 inches dbh. For trees 3-6 inches in dbh decay was sufficient to cause concern but varied from $0-72 \%$ of gross tree volume.

Table 2

HEIGHT, AGE, AND EXTENT OF DECAY OF ALPINE FIR FOR SIZE CLASSES UP TO 6.5 INCHES DBH

Trees

Average Average with Vol of

$\begin{array}{rrrr}\text { No. of age at height decay decay } & \text { (ft) } \\ \text { Size Class } & \text { trees ground }(\%)\end{array}$

\begin{tabular}{|c|c|c|c|c|c|c|}
\hline \multicolumn{7}{|l|}{ A. Logged ${ }^{1}$} \\
\hline $0--4.5 \mathrm{ft}$ & & 50 & 29 & 3.5 & 0.0 & 0.0 \\
\hline $0.0-0.5 \mathrm{in}$ & & 70 & 38 & 5.6 & 1.4 & 0.0 \\
\hline $0.6-1.5$ & & 50 & 52 & 8.3 & 4.0 & 0.6 \\
\hline $1.6-2.5$ & , & 50 & 65 & 14.0 & 8.0 & 2.1 \\
\hline $2.6-3.5$ & , & 50 & 78 & 17.8 & 14.0 & 0.5 \\
\hline $3.6-4.5$ & " & 50 & 97 & 23.4 & 28.0 & 1.9 \\
\hline $4.6-5.5$ & " & 45 & 108 & 28.8 & 22.2 & 0.7 \\
\hline $5.6-6.5$ & " & 50 & 112 & 35.2 & 48.0 & 4.1 \\
\hline$<0.6$ & , & 120 & 34 & 4.7 & 1.0 & 0.0 \\
\hline $0.6-2.5$ & " & 100 & 58 & 11.1 & 6.0 & 1.8 \\
\hline $2.6-6.5$ & , & 195 & 98 & 26.3 & 28.5 & 2.6 \\
\hline \multicolumn{7}{|l|}{ B. Unlogged ${ }^{2}$} \\
\hline $0-4.5 \mathrm{ft}$ & & 150 & 44 & 3.4 & 0.7 & 0.0 \\
\hline $0.0-0.5 \mathrm{in}$ & & 140 & 50 & 5.4 & 1.4 & 0.0 \\
\hline $0.6-1.5$ & & 100 & 60 & 8.6 & 3.0 & 0.2 \\
\hline $1.6-2.5$ & , & 100 & 84 & 13.9 & 10.0 & 1.6 \\
\hline $2.6-3.5$ & , & 100 & 96 & 19.7 & 17.0 & 3.9 \\
\hline $3.6-4.5$ & " & 99 & 111 & 26.9 & 30.3 & 3.5 \\
\hline $4.6-5.5$ & , & 96 & 118 & 32.9 & 45.8 & 5.9 \\
\hline $5.6--6.5$ & . & 84 & 133 & 41.8 & 46.4 & 8.7 \\
\hline$<0.6$, & , & 290 & 47 & 4.4 & 1.0 & 0.0 \\
\hline $0.6-2.5$ & , & 200 & 72 & 11.2 & 6.5 & 1.3 \\
\hline $2.6-6.5$ & ", & 379 & 114 & 29.7 & 34.3 & 6.7 \\
\hline \multicolumn{7}{|c|}{ C. All samples } \\
\hline $0-4.5 \mathrm{ft}$ & & 200 & 41 & 3.4 & 0.5 & 0.0 \\
\hline $0.0-0.5 \mathrm{in}$ & & 210 & 46 & 5.4 & 1.4 & 0.0 \\
\hline $0.6-1.5$ & $"$ & 150 & 58 & 8.4 & 3.3 & 0.3 \\
\hline $1.6-2.5$ & $"$ & 150 & 78 & 13.9 & 9.3 & 1.7 \\
\hline $2.6-3.5$ & ", & 150 & 90 & 19.0 & 16.0 & 2.8 \\
\hline $3.6-4.5$ & $"$ & 149 & 106 & 25.8 & 29.5 & 3.0 \\
\hline $4.6-5.5$ & ", & 141 & 115 & 31.6 & 39.0 & 4.4 \\
\hline $5.6-6.5$, & $"$ & 134 & 125 & 39.6 & 47.0 & 7.2 \\
\hline$<0.6$ & $"$ & 410 & 44 & 4.5 & 1.0 & 0.0 \\
\hline $0.6-2.5$, & $"$ & 300 & 68 & 11.2 & 6.3 & 1.4 \\
\hline $2.6-6.5$, & " & 574 & 108 & 28.6 & 32.4 & 5.4 \\
\hline
\end{tabular}

${ }^{1}$ Average number of years since logging was 10.

Includes 2 plots logged 1 year before examination.
Decay in Relation to Logged and Unlogged Stands

Within the same diameter class there was considerably less decay in logged stands than in unlogged stands (Table 2). The volume of decay in trees 3-6 inches dbh in logged stands averaged $2.6 \%$ and in unlogged $6.7 \%$. In the former, decay was serious only in the 6 -inch class. For corresponding diameter classes, the age of alpine fir in the logged stands was less than in the unlogged stands, presumably because of a rapid increase in growth after logging.

\section{Decay in Relation to Suspect Indicators}

Trees in Class I had much less decay than those in Class II (Fig. 2). Twenty-one per cent of all trees 3-6 inches dbh in Class I were infected and decay amounted to $2.4 \%$, while $51 \%$ of the trees in Class II were infected and decay was $9.7 \%$. In logged stands, decay occurred in $16 \%$ of the Class I trees 3-6 inches dbh and amounted to $0.4 \%$ of gross volume; this compared to $46 \%$ and $4.8 \%$ respectively for Class II trees.

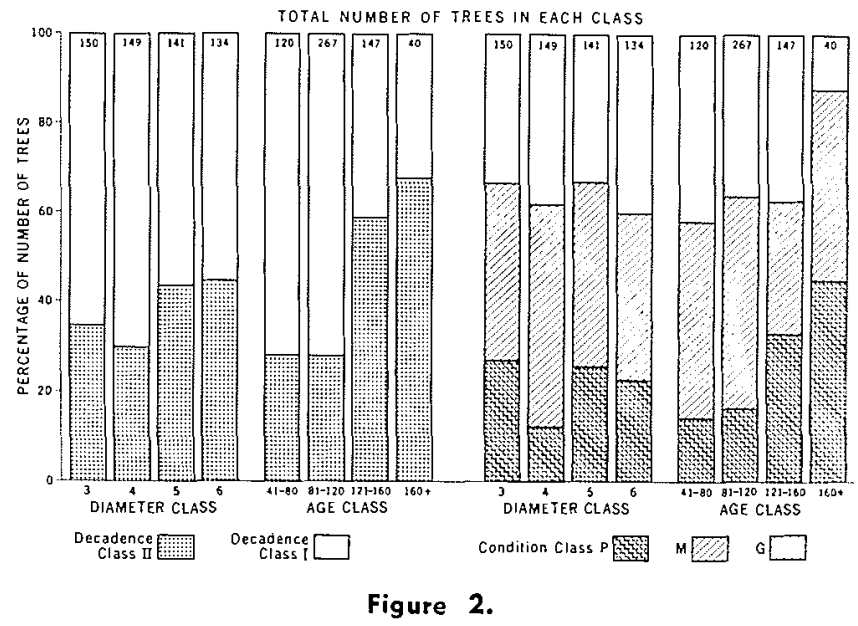

A comparison of the extent of decay among three tree condition classes ( $G=$ Good; $M=$ Moderate; $P=$ Poor), and be. tween two decadence classes (I - no suspect indicators; II with suspect indicators).

The proportion of trees with suspect indicators was associated more with age than with diameter (Fig. 3). Twenty-eight per cent of the trees 41.80 years of age were suspect compared to $68 \%$ of those 161 years and over.

Indian paint fungus conks (Echinodontium Tinctorium Ell. \& Ev.) indicated decay in all cases but were sparsely distributed. Reasonably reliable indicators were broken tops, dead branch stubs, dead tops, scars, crooks with dead secondary leaders and dead secondary leaders alone (Table 3 ). Broken branch stubs were common on most trees, but constituted a suspect indicator only when they occurred in large numbers or were visibly rotten.

Many suspect indicators were of no value in predicting the presence of decay. For example, of 219 crooks dissected, only one yielded decay. Other 
non-indicators were swellings, crooks with green secondary leaders, forks, dead branches, and burls.
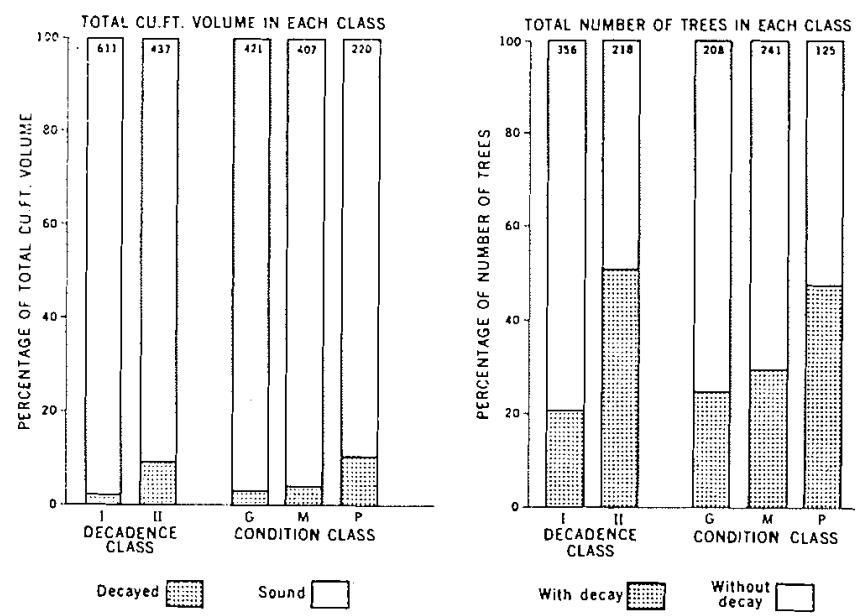

Figure 3.

The distribution of trees of each decadence class (I - no suspect indicators; 11 - with suspect indicators) and condition class ( $G=$ Good; $M=$ Moderate; $P=$ Poor) among diometer and age classes.

Table 3

PERCENTAGE OF SUSPECT POINTS OF ALPINE FIR THAT WERE INFECTED

\begin{tabular}{|c|c|c|c|c|}
\hline \multirow[b]{2}{*}{$\begin{array}{l}\text { Suspect } \\
\text { characteristic }\end{array}$} & \multicolumn{2}{|c|}{$0.0-2.5^{\prime \prime}$} & \multicolumn{2}{|c|}{$2.6-6.5^{\prime \prime}$} \\
\hline & $\begin{array}{l}\text { Number } \\
\text { of } \\
\text { dissec- } \\
\text { tions }\end{array}$ & $\begin{array}{c}\% \\
\text { with } \\
\text { decay }\end{array}$ & $\begin{array}{l}\text { Number } \\
\text { of } \\
\text { dissec- } \\
\text { tions }\end{array}$ & $\begin{array}{c}\% \\
\text { with } \\
\text { decay }\end{array}$ \\
\hline $\begin{array}{l}\text { Indian paint fungus } \\
\text { conks }\end{array}$ & 0 & - & 10 & 100.0 \\
\hline Broken tops & 2 & 0.0 & 7 & 57.2 \\
\hline Dead branch stubs & 46 & 19.6 & 179 & 29.6 \\
\hline Dead tops & 10 & 0.0 & 22 & 18.2 \\
\hline Scars & 252 & 1.6 & 366 & 17.5 \\
\hline $\begin{array}{l}\text { Crook and dead } \\
\text { secondary leaders }\end{array}$ & 345 & 0.9 & 176 & 13.1 \\
\hline $\begin{array}{l}\text { Dead secondary } \\
\text { leaders alone }\end{array}$ & 119 & 1.7 & 128 & 7.8 \\
\hline Dead branches & 53 & 1.9 & 142 & 0.7 \\
\hline Crooks & 282 & 0.0 & 219 & 0.5 \\
\hline Swellings & 97 & 0.0 & 111 & 0.0 \\
\hline $\begin{array}{l}\text { Crook and green } \\
\text { secondary leaders }\end{array}$ & 80 & 0.0 & 52 & 0.0 \\
\hline Forks & 19 & 0.0 & 14 & 0.0 \\
\hline $\begin{array}{l}\text { Dead secondary } \\
\text { leader and swellings }\end{array}$ & 3 & 0.0 & 2 & 0.0 \\
\hline Burls & 8 & 0.0 & 2 & 0.0 \\
\hline
\end{tabular}

\section{Decay in Relation to Age}

Ages of the trees examined varied from 7 to 246 years, with a wide range occurring even within a single diameter class. The older trees within each diameter class were more seriously decayed than the younger ones. Trees over 160 years of age in the 4 and 5 -inch $\mathrm{dbh}$ classes had a greater percentage of decay than trees less than 141 years of age in the 6 -inch dbh class. This occurred even though there was an average increase in decay with increasing diameter when age was discounted.

The relationship of age, diameter, and decadence class to percentage of decay in individual trees was tested by multiple linear regression analysis. The resulting relationship was highly significant but accounted for only $17 \%(R=0.41)$ of the total variation (Table 4). Unexplained variation was assumed to be random, non-linear, or associated with variables not measured (e.g., the time of year of injury could influence the susceptibility of alpine fir to infection by wood destroying fungi). Addition of diameter to the regression did not significantly add to the amount of variation explained by age and decadence class (Table 4). Decay was generally negligible up to age 50 for Class 11 trees and to age 80 for Class I trees; decay was unimportant for Class II trees less than 80 years and Class I trees less than 110 years of age. Considerable decay occurred in older trees, being especially serious in those over 160 years of age.

Table 4

ANALYSIS OF VARIANCE OF A LINEAR REGRESGRESSION DEFINING THE RELATIONSHIP BETWEEN DIAMETER $\left(\mathrm{X}_{1}\right)$, AGE $\left(\mathrm{X}_{2}\right)$, DECADENCE CLASS $\left(\mathrm{X}_{3}\right),{ }^{1}$ AND PERCENTAGE OF DECAY (Y)

$$
\mathrm{Y}=-.20 \mathrm{X}_{1}+.11 \mathrm{X}_{2}+2.9 \mathrm{X}_{3}-10.3
$$

\begin{tabular}{lrrrl}
\hline Source & DF & SS & MS & \multicolumn{1}{c}{ VR } \\
\hline $\begin{array}{l}\text { Regression } \\
\mathrm{X}_{1}+\mathrm{X}_{2}+\mathrm{X}_{3}\end{array}$ & 3 & 15,720 & 5,240 & $\begin{array}{l}58.8 \\
\mathrm{P}<.005\end{array}$ \\
$\begin{array}{l}\text { Residual } \\
\text { variance }\end{array}$ & 869 & 77,461 & 89.1 & \\
$\begin{array}{l}\text { Total variance Y } \\
872\end{array}$ & 93,181 & & \\
\hline $\begin{array}{l}\text { Contribution } \\
\text { of X2 } \mathrm{X}_{3}\end{array}$ & 2 & 15,663 & 7,831 & \\
$\begin{array}{c}\text { Additional } \\
\text { contribution of } \mathrm{X}_{1}\end{array}$ & 1 & 57 & 57 & $\begin{array}{l}0.6 \mathrm{~N} . \mathrm{S} . \\
\mathrm{P}<.250\end{array}$ \\
& & & &
\end{tabular}

${ }^{1}$ Class $\mathrm{I}=1 ;$ Class II $=2$

The average age of the sample trees 3-6 inches $\mathrm{dbh}$ from each plot correlated significantly with average percentage of decay (Fig. 4) and with the percentage of trees infected (Fig. 5), accounting for $49 \%$ and $31 \%$ of the variations respectively.

Ages used in the previous calculations were taken at ground level. Because ages are often more conveniently taken at other heights, an average relationship of height above ground to 4 feet and age is presented (Table 5). This relationship was similar for all sites, suppression apparently overriding any site differences. 


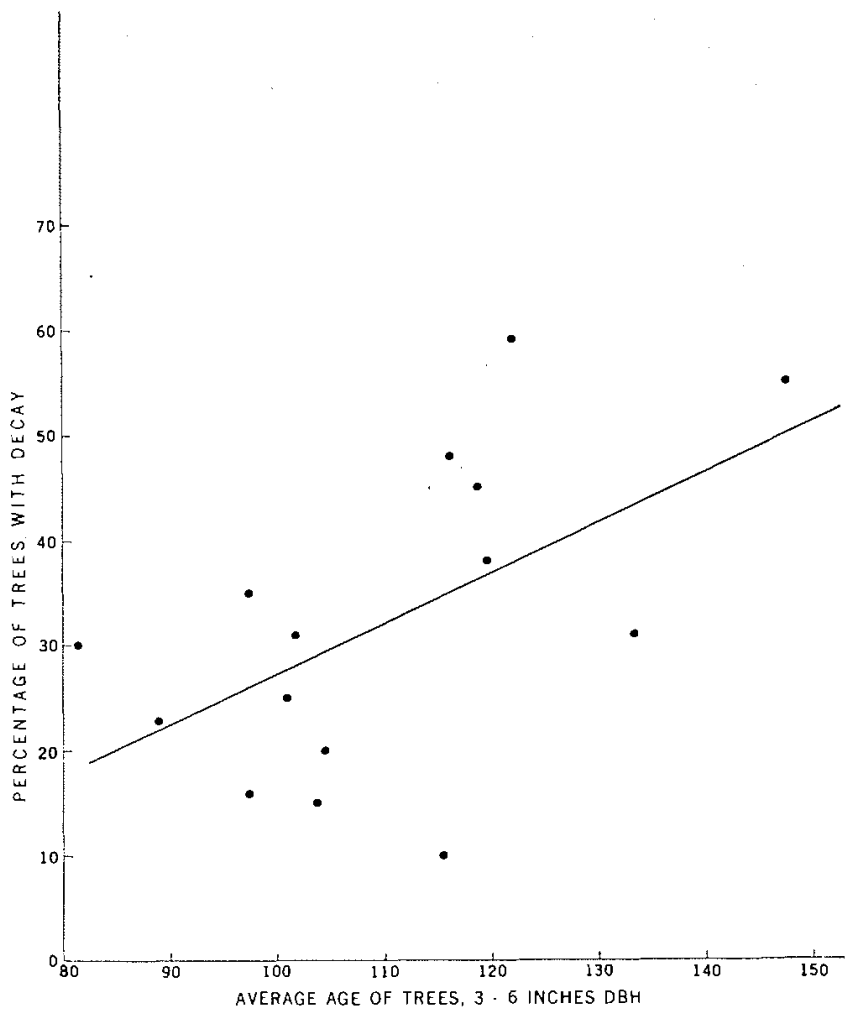

Figure 4.

Relationship between the average percentage of decay and the avercge age of alpine fir $3-6$ inches $\mathrm{dbh}$ for 15 plots. $Y=$ .27 $X-18.2, r=0.70, P<.005$.

\section{Table 5}

AVERAGE NUMBER OF YEARS TO BE ADDED TO AGES COUNTED AT FOUR LEVELS ABOVE GROUND TO ESTIMATE TOTAL TREE AGE ${ }^{1}$

\begin{tabular}{cc}
$\begin{array}{c}\text { Height above } \\
\text { ground (ft.) }\end{array}$ & $\begin{array}{c}\text { Number of years to add } \\
\text { for total tree age }\end{array}$ \\
\hline 0 & 0 \\
1 & 15 \\
2 & 25 \\
3 & 32 \\
4 & 37 \\
\hline
\end{tabular}

${ }^{1}$ Based on 860 trees

\section{Decay in Relation to Tree Condition}

Nearly twice the number of infected trees and over twice the volume of decay occurred in trees in poor condition than in trees in either the moderate or good classes. Trees in the latter two classes displayed fairly similar decay patterns.

In the 3-6-inch dbh classes, the proportion of poor trees was related to age rather than diameter, increasing from $14 \%$ at $41-80$ years of age to $45 \%$ over 160 years (Fig. 3 ).

Tree condition was not a valid indicator of decay for trees under 3 inches dbh. Many were classified as poor, but were found relatively free of decay. Poor crown condition was often due to attacks by the spruce budwarm (Choristoneura Fumiferana Cllm.).

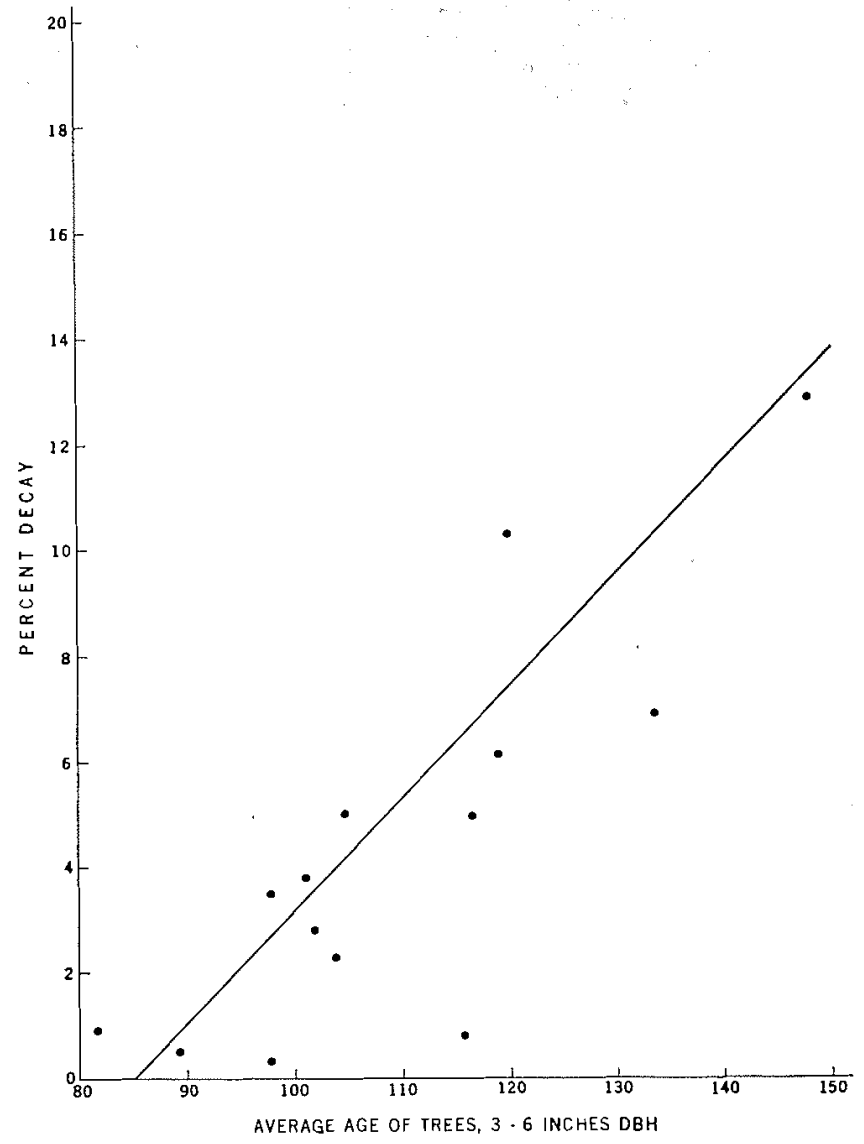

Figure 5.

Relationship between the percentage of trees infected and the average age of Alpine fir 3-6 inches $d b h$ for 15 plots. $\gamma=.48 X-20.5, r=0.56, P<.05$.

\section{Decay in Relation to Site}

There was considerable plot to plot variation in the extent and incidence of decay in the Oplopanax and Aralia-Dryopteris sites (Table 6). Trees from plots located in the Cornus-Moss type, however, had a consistently low decay volume and incidence. These low volumes may have been biased by the location of the plots which were either east or south

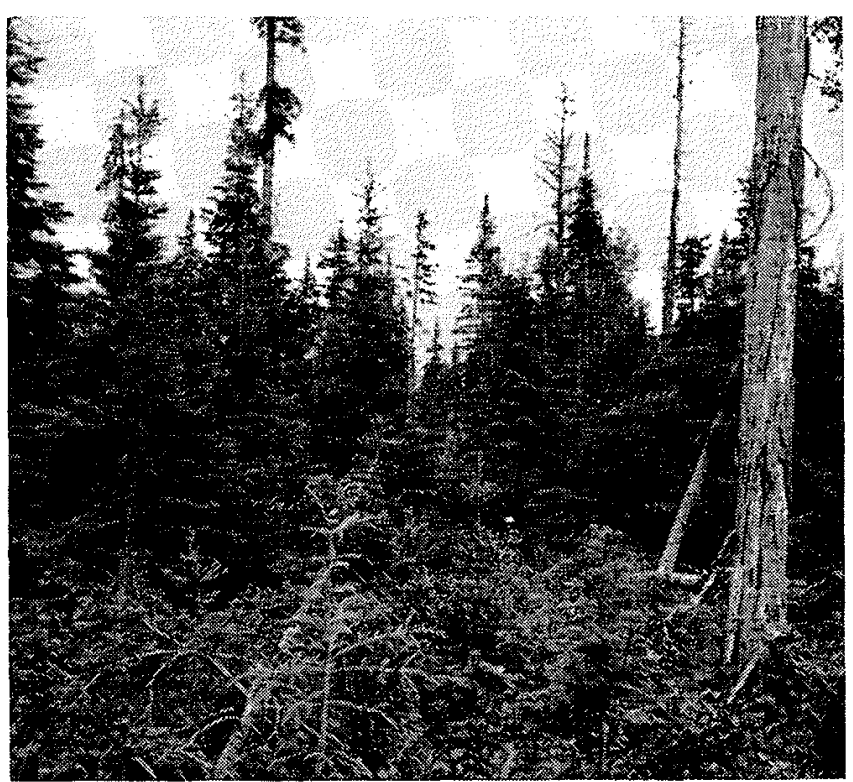

June 1968 The Forestry Chronicle 
RELATIONSHIP OF SITE AND AREA ${ }^{1}$ WITH VOLUME AND INCIDENCE OF DECAY IN ADVANCED ALPINE FIR REGENERATION 1-6 INCHES DBH

\begin{tabular}{lrrrrr}
\hline & \multirow{2}{*}{$\begin{array}{c}\text { No. of } \\
\text { plots }\end{array}$} & Average & Range & Average & Range \\
\cline { 5 - 6 } & & & & & \\
\hline Site & 4 & 6.0 & $(0.5-18.4)$ & 25 & $(15-42)$ \\
Oplopanax & 7 & 6.5 & $(0.8-10.0)$ & 29 & $(20-40)$ \\
Aralia - Dryopteris & 4 & 2.2 & $(0.3-4.9)$ & 12 & $(8-18)$ \\
Cornus - Moss & & & & & \\
Area & 5 & 10.0 & $(3.7-18.4)$ & 33 & $(17-42)$ \\
North and Northwest & 10 & 2.9 & $(0.3-6.7)$ & 19 & $(8-30)$ \\
East and South & & & & & \\
\hline
\end{tabular}

${ }^{1}$ Direction from Prince George

of Prince George; plots in these areas had considerably less decay than plots from other areas (Table 6 ). Age may be partially responsible for this difference, as sample trees from areas east and south of Prince George averaged 26 years younger than those from the other areas.

\section{Fungi Involved}

Forty-three per cent of the decay was initially attributed to the Indian paint fungus, and $32 \%$ to the bleeding conk (Stereum Sanguinolentum (Alb. \& Schw. ex. Fr.) Fr.) (Table 7). Odontia Bicolor (Alb. \& Schw. ex. Fr.) Bres., which causes a white stringy butt rot, was responsible for $5.1 \%$ of the decay volume. The causal fungi of a number of decay samples, representing $17.9 \%$ of the decay volume, were not obtained in culture. Using the identified samples as a guide, it was possible to assign causal fungi to many of these unknowns. Data before and after visual separation are shown in Table 7.

Numerous cultures were made from brown areas associated with very suppressed growth; however, no wood destroying fungi were isolated.

The entrance point of $\mathbf{E}$. Tinctorium was presumed to be branch stubs in most cases, but scars and crooks with dead leaders were also implicated. S. Sanguinolentum usually entered through scars, but branch stubs, dead secondary leaders, and broken tops, also served as entrance courts.

Table 7

BASIDIOMYCETES ASSOCIATED WITH TRUNK AND BUTT ROTS OF ALPINE FIR ADVANCED REGENERATION

\begin{tabular}{|c|c|c|c|c|}
\hline \multirow{2}{*}{ Organism } & \multicolumn{2}{|c|}{ Before visual separation } & \multicolumn{2}{|c|}{ After visual separation } \\
\hline & $\%$ of cultures & $\begin{array}{l}\% \text { of decay } \\
\text { volume }\end{array}$ & $\%$ of cultures & $\begin{array}{c}\% \text { of decay } \\
\text { volume }\end{array}$ \\
\hline \multicolumn{5}{|l|}{ Trunk rots White } \\
\hline Echinoedontium tinctorium Ell. \& Ev. & 18.4 & 43.1 & 27.4 & 51.0 \\
\hline Stereum sanguinolentum (Alb. \& Schw. ex. Fr.) Fr. & 19.8 & 31.7 & 33.1 & 37.6 \\
\hline Polyporus subcartilagineus Overh. & 0.8 & 1.1 & 0.8 & 1.1 \\
\hline Stereum chailletii (Pers. ex Fr.) Fr. & 0.4 & 0.1 & 0.4 & 0.1 \\
\hline Unknown & 30.2 & 14.7 & 8.1 & 0.9 \\
\hline Unknown & 0.8 & 0.5 & 0.8 & 0.5 \\
\hline \multicolumn{5}{|l|}{ Butt rots } \\
\hline Odontia bicolor (Alb. \& Schw. ex Fr.) Bres. & 14.5 & 5.1 & 14.5 & 5.1 \\
\hline Armillaria mellea (Fr.) Kumm. & 2.0 & 0.1 & 2.0 & 0.1 \\
\hline Corticium galactinum (Fr.) Burt & 1.2 & 0.6 & 1.2 & 0.6 \\
\hline Poria tsugina (Murr.) Sacc. \& Trott & 0.4 & $\mathrm{~T}^{1}$ & 0.4 & $\mathrm{~T}$ \\
\hline Unknown & 8.5 & 1.5 & 8.5 & 1.5 \\
\hline Brown & & & & \\
\hline Polyporus hirtus Quel. & 0.4 & 0.2 & 0.4 & 0.2 \\
\hline Poria asiatica (Pilat) Overh. & 0.4 & $\mathrm{~T}$ & 0.4 & $\mathrm{~T}$ \\
\hline Coniophora puteana (Schum. ex Fr.) Karst & 0.4 & $\mathrm{~T}$ & 0.4 & $\mathrm{~T}$ \\
\hline Unknown & 1.6 & 1.2 & 1.6 & 1.2 \\
\hline
\end{tabular}

$$
{ }^{1} \mathrm{~T}=\text { trace }
$$




\section{Post-logging Growth}

Growth of alpine fir up to 7 inches dbh was good in all plots after logging and exceptional in individual cases. Average height growth (Fig. 6) was 1.5-4.5, and diameter growth 1.6-3.4 times as great as before logging. Annual growth increments increased for 6-8 years after logging and then maintained a constant rate. The best growth response occurred in trees which were less than the maximum size sampled, and which at the time of logging were 2-4 inches $\mathrm{dbh}$.

The amount of growth response appeared to depend on the density of overtopping residuals, which varied greatly from area to area and even within the same plot.



Figure 6.

Average annual height growth since. logging for 1 to 6 -inch dbh olpine fir from four plots.

\section{Discussion and Conclusions}

The age, condition, and extent of decay of alpine fir understory less than 7 inches $\mathrm{dbh}$ is highly variable and generalizations concerning its probable economic value are ill-advised. These data suggest that portions of this understory are potentially productive and should not be disregarded.

Because decay is more closely associated with age than with diameter it is reasonable to expect that if it is not suppressed, alpine fir can reach merchantable size before decay becomes serious. The low amount of decay in young evenaged stands of alpine fir reported by Bier et al. (1948) supports this view. Unfortunately, unevenaged stands are widespread and in most of them the understory is severely suppressed. When released by logging, however, understory trees, especially those 2-4 inches dbh, show good growth response.
Much of the additional growth after logging may be wasted on undesirable trees (Fraser and Alexander, 1949); therefore, improvement cuttings designed to reduce the proportion of poor risk trees are recommended. Age measurements are time consuming so poor risk trees must be selected on the basis of diameter (there are more old trees in the large diameter classes than in the small), and decadence class. The following basic procedures for improvement of areas of white spruce-alpine fir advanced regeneration are suggested:

1. Fell all residual trees over 6 inches dbh. In addition to improving the growth of smaller trees, removal of the overstory will reduce the amount of scarring and top and branch breakage caused by the windthrow of declining trees. The importance of scars in alpine fir as avenues of entrance for decay fungi has been investigated previously (Parker and Johnson, 1960).

2. Remove alpine fir from the 3-6 inch diameter classes having any of the following suspect indicators: conks, scars, broken tops, numerous or rotten branch stubs, dead tops, crooks with dead secondary leaders, and dead secondary leaders alone. No treatment of trees smaller than 3 inches $\mathrm{dbh}$ is required. An advantage of retaining alpine fir advanced regeneration besides reducing the long regeneration period, is that shade enhances the survival of white spruce regeneration (Pogue, 1946; Smith, 1955). This beneficial effect may, however, be short term (Eis, 1966). It is conceded that suppression will still occur in some of the smallest trees in dense clumps; however, this will not be nearly as severe as in selectively logged stands or in areas "clear-cut" to 11 inches, a practice common in the interior of British Columbia in the past (Nixon, 1955).

\section{Plant or seed understocked portions.}

Because of low decay volumes, removal of poor risk trees 3-6 inches dbh from stands in the dry Cornus-Moss type and in stands in which the understory is relatively young (e.g., average age of trees 3-6 inches less than 100 years), can be assigned a low priority. Removal of the residual overstory over 6 inches dbh is recommended as outlined previously.

The pattern of decay in stands in which a period of time has elapsed since logging, differs from that in unlogged or very recently logged areas, and treatment measures must be adjusted accordingly. The diameter at which decay becomes serious will generally be higher in the former case-just how high will depend on the age and growth rate of the alpine fir and the number of years since logging.

\section{Acknowledgments}

The authors are grateful to Miss D. Chu, Forest Research Laboratory, Victoria, for identification of fungi in culture. 


\section{References}

ADDISON, JOHN. 1966. Regeneration of spruce. B. C. Lumberman $50(6): 42-48$.

BIER, J. E., P. J. SALISBURY, and R. A. WALDIE. 1948. Decay in fir, Abies lasiocarpa and A. Amabilis in the Upper Fraser Region of British Columbia. Dominion of Canada, Dept. of Agr., Tech. Bull. $66,28 p+5$ plates.

BRITISH COLUMBIA FOREST SERVICE. 1966. Net volume (loss) factors. B. C. Dept. of Lands, Forests, and Water Resources, For. Survey Note 8, 80p.

BROWNE, J. E. 1952. Decay of Engelmann spruce and balsam fir in the Bolean Lake area, B. C. Laboratory of Forest Biology, Victoria, B. C., 24p (mimeo).

DICKSON, F. 1927. A study of heart-rot in the amabilis fir (Abies amabilis) in the Upper Fraser Region of British Columbia. Dept. of Botany, Univ. of B. C., $44 p$ (typewritten).

EIS, S. 1966. Survival and growth of white spruce wildlings and coastal nursery seedlings in the interior of British Columbia. For Chron. 42: 346-349.

FOSTER, R. E., G. P. THOMAS, and J. E. BROWNE. 1953. A tree decadence classification for mature coniferous stands. For. Chron. 29: 359-366.

FRASER, A. R., and J. L. ALEXANDER. 1949. The development of the spruce-balsam type in the Aleza Lake Experimental Forest. B. C. Forest
Service, Tech. Publ. T. 32, 41p.

ILLINGWORTH, K., and J. W. C. Arlidge. 1960. Interim report on some forest site types in lodgepole pine and spruce-alpine fir stands. B. C. Forest Service, Res. Note 35, 44p.

KRAJINA, V. J. 1965. Biogeoclimatic zones and classification of British Columbia, p 1-17. In V. J. Krajina (ed.), Ecology of Western North America, Vol. 1. Dept. Bot., Univ. of B. C., Vancouver, B. C. McKINNON, F. S. 1940. Spruce regeneration in British Columbia. For. Chron. 16 (Special No.): 37-44.

NIXON, G. R. W. 1955. A logging study in a typical overmature spruce-balsam forest of the southern interior of British Columbia. B. C. Lumberman 39: 44-50, 54.

PARKER, A. K., and A. L. S. JOHNSON. 1960. Decay associated with logging injury to spruce and balsam in the Prince George Region of British Columbia. For. Chron. 36: 30-45.

POGUE, H. M. 1946. Regeneration and growth of white spruce after logging. B. C. Forest Service, Tech. Publ. T. 29, 26p.

SILBURN, George. 1960. Reforestation problems in western spruce forests. For. Chron. 36: 150-152, 155.

SMITH, J. H. G. 1955. Some factors affecting reproduction of Engelmann spruce and alpine fir. B.C. Forest Service Tech. Publ. T. 43, 43p.

\section{CANADIAN FORESTRY EDUCATION}

To the man interested in Forestry as a coreer, Canadian schools offer education at all levels.

\section{Professional Training}

The four University Forestry Faculties, listed below offer instruction aimed at understanding of fundamental forestry principles, and training in courses of an applied nature best suited to the needs of the forest regions they serve. Opportunities for post-graduate study are also available of the following: -

\section{University of New Brunswick, Fredericton, N.B. \\ L'Université Laval, Quebec 10, P.Q. \\ University of Toronto, Toronto, Ontario \\ University of British Columbia, Vancouver, B.C.}

\section{Technological and Vocational Training}

These courses are designed to provide men with an adequate knowledge of the theory and practice of Forestry, Logging and Milling so that they may, with adequate on-the-job-experience, serve as an intelligent line of communication and action between the professional forester and the forest labourer.

Two year courses in Forest Technology are offered by: -

Nfld. College of Trades \& Technology, St. John's, Nfld.

Lakehead University, Port Arthur, Ontario

Northern Alberta Institute of Technology, Edmonton, Alta.

Saskatchewan Technical Institute, Saskatoon, Saskatchewan

British Columbia Institute of Technology, Burnaby, B.C.

One year courses of technical training in Forestry are offered at the following Ranger Schools: -

Maritime Forest Ranger School, Fredericton, N.B.

L'Ecole Forestiere de Duchesnay, Quebec, P.Q.

Ontario Forest Technical School, Dorset, Ontario

B.C. Forest Training School, North Surrey, B.C.

The B.C. school is limited to in-service training.

For information regarding entrance requirements, courses of study, field training or facilities for specialization at any of the above, please write directly to the school in questions. 